\title{
Heavy Metal Concentrations in Free-Living Southern Caracaras (Caracara plancus) in the Northeast Region of Brazil
}

\author{
Luana Thamires Rapôso da Silva', Emanuel Felipe de Oliveira Filho' ${ }^{1}$, Taciana de Holanda Kunst ${ }^{2}$, \\ Vitor Pereira Matos Rolim', José Sérgio de Alcântara e Silva ${ }^{3}$, Rodrigo Farias Silva Regueira, \\ Ana Paula Silveira Paim², Pierre Castro Soares' \& Andréa Alice da Fonseca Oliveira'
}

\begin{abstract}
Background: With the continuously increasing release of heavy metals in the environment, mostly from anthropogenic sources, there is a need to find ways of evaluating and managing the issuance of these contaminants and correct its damages. The birds being at the top of some food chains reflect the presence of metals in the environment, keeping this in perspective, raptors have been successfully used for heavy metals biomonitoring studies in the past. The purpose of this study was to identify and quantify cadmium $(\mathrm{Cd})$, mercury $(\mathrm{Hg})$, lead $(\mathrm{Pb})$, copper $(\mathrm{Cu})$, and chromium $(\mathrm{Cr})$ in the feathers and livers of free-living southern caracaras, live and dead, from Recife, Pernambuco state, Northeast of Brazil.

Material, Methods \& Results: Sixty-two feathers from live and dead southern caracaras and 21 livers from dead southern caracaras were analyzed by atomic absorption spectrometry for $\mathrm{Hg}$ and by inductively coupled plasma optical emission spectrometry for $\mathrm{Cd}, \mathrm{Cr}, \mathrm{Pb}$, and $\mathrm{Cu}$. Concentrations of $\mathrm{Cr}$ and $\mathrm{Cu}$ elements were detected in all feather and liver samples analyzed from live and dead caracaras. There was no difference in the concentration of metals between feathers of dead and live caracaras: $\mathrm{Pb}(P=0.3576), \mathrm{Cd}(P=0.0792), \mathrm{Cr}(P=0.5475)$, and $\mathrm{Cu}(P=0.3603)$, but significant variation was observed for $\mathrm{Hg}(P=0.0459)$. The highest concentrations of $\mathrm{Pb}(P<0.0001)$ and $\mathrm{Cr}(P<0.0001)$ were found in the feathers than in the liver. On the other hand, the highest concentrations of $\mathrm{Cu}$ were found in liver samples $(P=0.0011)$. No significant variation in the concentrations of $\mathrm{Cd}(P=0.7770)$ and $\mathrm{Hg}(P=0.3669)$ was found between feathers and liver samples. Discussion: Chromium, as well as $\mathrm{Hg}$, and $\mathrm{Cu}$ have a high affinity for keratin, which may explain the higher concentrations of $\mathrm{Cr}$ in caracaras feathers in this research. Lead was detected in all liver samples analyzed. Elevated levels were also found in the feathers of dead $(95.2 \%)$ and live $(75.6 \%)$ caracaras. The presence of $\mathrm{Pb}$ may be due to external contamination by pollutants, such as fossil fuels. Higher concentrations of $\mathrm{Hg}$ were observed in dead caracaras feathers, this concentrations change during molting but are not affected by external contamination. Metals, such as $\mathrm{Hg}$, and $\mathrm{Cd}$, accumulate in organisms from different trophic levels, which may indicate that this contamination comes mainly from feed. Pearson's coefficient here showed no correlation between metals from dead caracaras feathers and livers, although a few previous studies have shown a correlation between metal concentrations from tissues and feathers. This pattern can be attributed to the different time of exposure of feathers to metals in relation to livers. The concentrations of metals in hepatic tissues reflect the levels of elements in the diet of these birds, characterizing acutely the contamination of the ecosystem. On the other hand, feathers represent the exposure in the time of molting, when the artery supplies metals, thus representing a chronic exposure. In feathers from live birds, the Pearson's correlation analysis showed a high to moderate correlation between metals, which may suggest that they come from a similar source, but there is no way to specify the origin since the metals surveyed could be present in the soil, water, or in the prey eaten by these animals. For the purpose of environmental analyses, it is required to determine the exact source of contamination. Considering that it is possible to confirm the presence of these heavy metals in southern caracaras, these birds may be important environmental bioindicators. The development of systematic research on animals and the environment is essential for monitoring the levels of metal pollutants and evaluating their impact in order to guide measures to protect fauna and human health.
\end{abstract}

Keywords: environmental bioindicators, feather, poisoning, raptors, airport area. cal Development Support Center (CDT/UnB - Fauna Project) - Gilberto Freyre International Airport, Recife. CORRESPONDENCE: A.A.F. Oliveira [andreaafo@hotmail.com - Tel.: +55 (81) 33206430]. Veterinary Medicine Department, Federal Rural University of Pernambuco (UFRPE). Rua Dom Manoel de Medeiros, s/n. Bairro Dois Irmãos. CEP 52171-900 Recife, PE, Brazil. 


\section{INTRODUCTION}

Concerns about environmental contamination are increasing worldwide because of the influence that many common contaminants can have on fauna and flora $[1,20]$. Heavy metals contribute to this contamination as one of the major elements threatening ecosystem sustainability. They are present in every environment as a result of either natural geological cycles or human activities and can cause endocrine problems, nervous disorders, and genotoxicity in animals and humans [1,5].

Exposure to heavy metals and other pollutants is generally higher in animals that are at the top of a food chain, such as raptors $[1,9,19]$ and many are acquired by animals through food; once in the body, they undergo biochemical and physiological processes and are distributed or accumulated. In birds, a large proportion of metal is found in the feathers [19].

The southern caracara (Caracara plancus) is a raptor from the order Falconiformes and family Falconidae. In Brazil, it has large populations in the northeastern and southeastern regions [24]. Studies on the feeding habits of these birds have shown that they are opportunistic in nature [25] and are adapted to urban environments, as well as natural areas, and thus, are exposed to a diversity of chemical compounds [24].

The purpose of this study was to identify and quantify cadmium $(\mathrm{Cd})$, mercury $(\mathrm{Hg})$, lead $(\mathrm{Pb})$, copper $(\mathrm{Cu})$, and chromium $(\mathrm{Cr})$ in the feathers and livers of free-living southern caracaras, live and dead, from Recife, Pernambuco state, Northeast of Brazil.

\section{MATERIALS AND METHODS}

\section{Collection site and sampling}

The study was carried out with southern caracaras (Caracara plancus) captured at Recife/Guararapes Gilberto Freyre International Airport $\left(08^{\circ} 07^{\prime} 53^{\prime \prime} \mathrm{S}\right.$ and $\left.34^{\circ} 55^{\prime} 05^{\prime \prime} \mathrm{W}\right)$, which is an urban area located approximately $10 \mathrm{~km}$ from the central region of the Recife area, Pernambuco State, Northeast of Brazil, in partnership with the team of Fauna Project at the Brazilian Airports.

The site is characterized by disordered urban growth, presence of domestic effluents, and degraded environmental area near the airport. Furthermore, several commercial ventures that store fuels, such as gas stations and gas tanks are present nearby.
Sixty-two southern caracaras (Caracara plancus) collected by the team of Fauna Project at the Brazilian Airports were used in the study. The birds were captured using Tomahawk type traps that were arranged at the collection site. From the total number of birds collected, feather samples were obtained from 41 live birds and both feather and liver samples of 21 dead birds were obtained; the dead birds were victims of traumas resulting from collisions with aircrafts. The captured live birds were sent to the Technological Development Support Center located at the airport for collection of biological samples.

This research was carried out according to the license issued by Brazilian Institute of Environment and Renewable Natural Resources and the Ethics Committee on the Use of Animals from Federal Rural University of Pernambuco.

\section{Biological material collection}

Birds captured live were initially submitted to clinical examination meant to observe the general state of health. Later, two primary feathers were collected from each bird, conditioned in collectors (metal-free plastic) ${ }^{1}$, correctly identified, and stored in a freezer at $-20^{\circ} \mathrm{C}$ until the moment of digestion. From the dead birds, two primary feathers were collected from each wing and liver samples per bird, which were likewise stored in a freezer at $-20^{\circ} \mathrm{C}$ until the moment of digestion. Data were recorded in individual sheets and after analysis were arranged in a spreadsheet.

\section{Heavy metal analysis in feathers and livers}

Feathers were initially washed with acetone thrice while alternating with deionized water to remove any external contamination. Afterward, the feathers were oven dried at $60^{\circ} \mathrm{C}$ for $48 \mathrm{~h}$, ground, and weighed. The dry weights were adjusted from 0.01 to $0.09 \mathrm{~g}$ followed by the feathers being put in tubes containing $4 \mathrm{~mL}$ of $\mathrm{HNO}_{3}(65 \%)$ and $4 \mathrm{~mL}$ of $\mathrm{H}_{2} \mathrm{O}_{2}(30 \%)$. They were then placed in Mars ${ }^{\circledR}$ Microwave Digester ${ }^{2}$. The digestion was performed according to protocol previously established [7]. Subsequently, the samples were placed in falcon tubes $(15 \mathrm{~mL})$ and stored at room temperature until analysis.

For analysis of heavy metals in the liver samples, they were fragmented and cooked at $60^{\circ} \mathrm{C}$ for $24 \mathrm{~h}$. The dried livers were ground, placed in collectors, and 
the dry matter obtained was weighed. The weights were adjusted between 0.1 and $0.2 \mathrm{~g}$. The samples were then placed in tubes containing $4 \mathrm{~mL}$ of $\mathrm{HNO}_{3}(65 \%)$ and $4 \mathrm{~mL}$ of $\mathrm{H}_{2} \mathrm{O}_{2}(30 \%)$ followed by being placed in a Mars $^{\circledR}$ Microwave Digester $^{2}$ [7].

For quantification of $\mathrm{Pb}, \mathrm{Cd}, \mathrm{Cr}$, and $\mathrm{Cu}$ $(\mu \mathrm{g} / \mathrm{g})$ the digested samples were diluted using deionized water (1:10) and analyzed using an inductively coupled plasma optical emission spectrometer (ICP-OES, Optima $\left.7000 \mathrm{DV}^{\circledR}\right)^{3}$ with axial configuration. For quantification of $\mathrm{Hg}$, the samples were analyzed using an atomic absorption spectrophotometer (Varian AA240FS $\left.{ }^{\circledR}\right)^{4}$, with Hydride Generator Systems (model VGA 77) ${ }^{5}$. All samples were analyzed in batches with blanks and appropriate standards. The detection limits for each metal used in this study were established according to the equipment manufacturer.

\section{Data analysis}

The data were expressed considering measures of central tendency (mean, standard error, median, and percentiles of 25 and 75). The concentrations of metals, $\mathrm{Pb}, \mathrm{Cd}$, and $\mathrm{Hg}$, were treated with a root transformation of $\mathrm{x}+1$, whereas those of $\mathrm{Cr}$ and $\mathrm{Cu}$ were treated with $\log _{10}$ base transformation. After transformation, the data was treated with analysis of variance (Test $F$ ) to evaluate the effect of different variability factors (feathers of live and dead caracaras). Wherever there was significance in the F test, the means of the treatments were compared by the Student-Newman-Keuls test. Pearson's correlation coefficient (r) was determined for the categories: concentration of metals in feathers and liver of birds as well as feathers of live birds and the significance obtained in the correlation was analyzed [18]. The data was analyzed through the Statistical Analysis System (version for windows 9.2) ${ }^{6}$, using the General Linear Model (GLM) procedure of SAS. Samples yielding concentration values below the detection limits were removed from analysis and for all analysis, the significance level was set at $P<0.05$

\section{RESULTS}

All samples of feathers and livers of the analyzed birds contained $\mathrm{Cr}$ and $\mathrm{Cu}$. Among the live birds, feathers of $75.6 \%$ (31/41) birds had $\mathrm{Pb}, 26.8 \%$ (11/41) had Cd, and 24.4\% (10/41) had Hg. Among dead birds, feathers of $95.2 \%$ (20/21) birds had Pb,
52.4\% (11/21) had Cd, and 47.6\% (10/21) had Hg. Lead was found in all liver samples along with $\mathrm{Cd}$ that was found in $80.9 \%(17 / 21)$ of birds and $\mathrm{Hg}$ in $23.8 \%(5 / 21)$.

Mean values, standard error, median, and lower and upper limits of concentration of heavy metals in live and dead caracaras feathers are shown in Table 1. There was no significant difference in the concentrations of metals present in feathers of live and dead birds: $\mathrm{Pb}(P=0.3576), \mathrm{Cd}(P=0.0792), \mathrm{Cr}(P=$ $0.5475), \mathrm{Cu}(P=0.3603)$, but there was a significant variation in relation to $\mathrm{Hg}(P=0.0459)$ as shown in Figure 1.

Mean values, standard error, median, and lower and upper concentration limits of heavy metals in feathers and livers of dead caracaras are shown in Table 2.

Higher concentrations of $\mathrm{Pb}(P<0.0001)$ and $\mathrm{Cr}(P<0.0001)$ were found in feathers as compared to hepatic tissues in dead caracaras. The highest concentrations of $\mathrm{Cu}$ were found in liver samples $(P=0.0011)$ from dead birds as well. As for the concentrations of $\mathrm{Cd}$ $(P=0.7770)$ and $\mathrm{Hg}(P=0.3669)$, no significant difference was found between feathers and liver samples from dead caracaras.

In feathers of live caracaras, high positive correlation was observed between $\mathrm{Cd}$ and $\mathrm{Cr}(\mathrm{r}=$ $0.72, P<0.0001)$ as well as between $\mathrm{Cd}$ and $\mathrm{Cu}(\mathrm{r}=$ $0.63, P<0.0001)$. Moderate positive correlation was observed between $\mathrm{Pb}$ and $\mathrm{Cd}(\mathrm{r}=0.46, P=0.0002)$, $\mathrm{Pb}$ and $\mathrm{Cr}(\mathrm{r}=0.48, P=0.0017), \mathrm{Pb}$ and $\mathrm{Cu}(\mathrm{r}=0.41$, $P=0.0073), \mathrm{Cd}$ and $\mathrm{Hg}(\mathrm{r}=0.31, P=0.0493), \mathrm{Cr}$ and $\mathrm{Hg}(\mathrm{r}=0.36, P=0.0228)$ as well as $\mathrm{Cu}$ and $\mathrm{Hg}$ (r $=0.32, P=0.0407)$.

In the samples of dead caracaras feathers, there was a high positive correlation between $\mathrm{Pb}$ and $\mathrm{Cd}(\mathrm{r}=0.74, P<0.0001)$ and between $\mathrm{Cr}$ and $\mathrm{Cu}(\mathrm{r}=0.80, P<0.0001)$. A moderate positive relationship was observed between $\mathrm{Pb}$ and $\mathrm{Cr}(\mathrm{r}=0.49$, $P=0.0258)$ and between $\mathrm{Pb}$ and $\mathrm{Cu}(\mathrm{r}=0.57, P=$ 0.0069). In the samples of dead caracaras livers, a high positive correlation was observed between $\mathrm{Cu}$ and $\mathrm{Hg}(\mathrm{r}=0.79, P<0.0001)$. Moderate positive relation was observed between $\mathrm{Cd}$ and $\mathrm{Cu}(\mathrm{r}=0.43$, $P=0.0532)$ and between $\mathrm{Cd}$ and $\mathrm{Hg}(\mathrm{r}=0.51, P=$ 0.0172) [Table 3].

No relationship was found between the concentrations of heavy metals in feathers and livers of dead caracaras according to Table 4. 
Table 1. General media of metals from live and dead caracaras feathers in Pernambuco state, Brazil.

\begin{tabular}{|c|c|c|c|c|c|c|c|c|}
\hline \multirow{2}{*}{ Metal $(\mu \mathrm{g} / \mathrm{g})$} & \multirow{2}{*}{ Caracaras feathers } & \multicolumn{5}{|c|}{ Statistical measures } & \multirow{2}{*}{$\begin{array}{c}\text { Level of } \\
P\end{array}$} & \multirow{2}{*}{ General Media } \\
\hline & & Mean & SE* & Median & Lower & Upper & & \\
\hline \multirow{2}{*}{$\mathrm{Pb}$} & Live & $5.27 \mathrm{a}$ & 1.22 & 3.86 & 1.77 & 6.11 & \multirow{2}{*}{0.3576} & \multirow{2}{*}{5.36} \\
\hline & Dead & $5.44 \mathrm{a}$ & 0.78 & 5.30 & 3.15 & 7,31 & & \\
\hline \multirow{2}{*}{$\mathrm{Cd}$} & Live & $0.43 a$ & 0.13 & 0.00 & 0.00 & 0,89 & \multirow{2}{*}{0.0792} & \multirow{2}{*}{0.59} \\
\hline & Dead & $0.74 \mathrm{a}$ & 0.17 & 1.01 & 0.00 & 1.25 & & \\
\hline \multirow{2}{*}{$\mathrm{Cr}$} & Live & $3.84 \mathrm{a}$ & 0.48 & 2.71 & 2.27 & 4.18 & \multirow{2}{*}{0.5475} & \multirow{2}{*}{3.92} \\
\hline & Dead & $3.99 \mathrm{a}$ & 0.52 & 3.20 & 2.50 & 4.21 & & \\
\hline \multirow{2}{*}{$\mathrm{Cu}$} & Live & $10.75 \mathrm{a}$ & 1.48 & 7.50 & 6.29 & 10.67 & \multirow{2}{*}{0.3603} & \multirow{2}{*}{10.94} \\
\hline & Dead & $11.12 \mathrm{a}$ & 1.32 & 9.52 & 7.50 & 11.77 & & \\
\hline \multirow{2}{*}{$\mathrm{Hg}$} & Live & $0.12 b$ & 0.04 & 0.00 & 0.00 & 0.00 & \multirow{2}{*}{0.0459} & \multirow{2}{*}{0.52} \\
\hline & Dead & $0.91 \mathrm{a}$ & 0.54 & 0.00 & 0.00 & 0.26 & & \\
\hline
\end{tabular}

*Standard Error. Different lowercase letters in the same column represent a significant variation in concentration of metals on feathers and livers of dead caracaras and captured at the airport, for each metal, at a level of 5\% probability.

Table 2. General media of metals from feathers and liver of dead caracaras in Pernambuco state, Brazil.

\begin{tabular}{|c|c|c|c|c|c|c|c|}
\hline \multirow{2}{*}{ Metal $(\mu \mathrm{g} / \mathrm{g})$} & \multirow{2}{*}{ Sample } & \multicolumn{5}{|c|}{ Statistical measures } & \multirow{2}{*}{ Level of $P$} \\
\hline & & Mean & $\mathrm{SE}^{*}$ & Median & Lower & Upper & \\
\hline \multirow{2}{*}{$\mathrm{Pb}$} & Feathers & $5.44 \mathrm{a}$ & 0.78 & 5.30 & 3.15 & 7.31 & \multirow{2}{*}{$<0.0001$} \\
\hline & Liver & $1.36 \mathrm{~b}$ & 0.11 & 1.29 & 1.19 & 1.54 & \\
\hline \multirow{2}{*}{$\mathrm{Cd}$} & Feathers & $0.74 a$ & 0.17 & 1.01 & 0.00 & 1.25 & \multirow{2}{*}{0.7770} \\
\hline & Liver & $0.45 a$ & 0.09 & 0.37 & 0.19 & 0.68 & \\
\hline \multirow{2}{*}{$\mathrm{Cr}$} & Feathers & $3.99 a$ & 0.52 & 3.20 & 2.50 & 4.21 & \multirow{2}{*}{$<0.0001$} \\
\hline & Liver & $1.35 \mathrm{~b}$ & 0.09 & 1.28 & 1.14 & 1.46 & \\
\hline \multirow{2}{*}{$\mathrm{Cu}$} & Feathers & $11.12 b$ & 1.32 & 9.52 & 7.50 & 11.77 & \multirow{2}{*}{0.0011} \\
\hline & Liver & $17.03 \mathrm{a}$ & 2.07 & 15.17 & 13.02 & 18.46 & \\
\hline \multirow{2}{*}{$\mathrm{Hg}$} & Feathers & $0.91 \mathrm{a}$ & 0.54 & 0.00 & 0.00 & 0.26 & \multirow{2}{*}{0.3691} \\
\hline & Liver & $0.44 \mathrm{a}$ & 0.30 & 0.00 & 0.00 & 0.00 & \\
\hline
\end{tabular}

*Standard Error. Different lowercase letters in the same column represent a significant variation in concentration of metals on feathers and livers of dead caracaras and captured at the airport, for each metal, at a level of $5 \%$ probability.

Table 3. Pearson correlation matrix for concentration of metals $(\mu \mathrm{g} / \mathrm{g})$ in liver from dead caracaras in Pernambuco state, Brazil.

\begin{tabular}{cccccc}
\hline Metal & $\mathrm{Pb}$ & $\mathrm{Cd}$ & $\mathrm{Cr}$ & $\mathrm{Cu}$ & $\mathrm{Hg}$ \\
\hline \multirow{2}{*}{$\mathrm{Pb}$} & \multirow{2}{*}{1} & -0.05 & -0.13 & 0.06 & -0.09 \\
& & 0.8264 & 0.5681 & 0.8005 & 0.6963 \\
$\mathrm{Cd}$ & 1 & 0.14 & 0.43 & 0.51 \\
& & & 0.5463 & 0.0532 & 0.0172 \\
$\mathrm{Cr}$ & & 1 & -0.02 & -0.18 \\
& & & 0.9353 & 0.4461 \\
$\mathrm{Cu}$ & & & 1 & 0.79 \\
$\mathrm{Hg}$ & & & & $<0.0001$ \\
\hline
\end{tabular}


Table 4. Pearson correlation matrix for concentration of metals $(\mu \mathrm{g} / \mathrm{g})$ in feathers and liver of dead caracaras in Pernambuco state, Brazil.

\begin{tabular}{|c|c|c|c|c|c|}
\hline Metal & Feather $\mathrm{Pb}$ & Feather Cd & Feather $\mathrm{Cr}$ & Feather $\mathrm{Cu}$ & Feather $\mathrm{Hg}$ \\
\hline Liver $\mathrm{Pb}$ & $\begin{array}{c}-0.16576 \\
0.4727\end{array}$ & & & & \\
\hline Liver Cd & & $\begin{array}{c}0.18967 \\
0.4102\end{array}$ & & & \\
\hline Liver $\mathrm{Cr}$ & & & $\begin{array}{c}-0.13383 \\
0.5630\end{array}$ & & \\
\hline Liver $\mathrm{Cu}$ & & & & $\begin{array}{c}-0.06944 \\
0.7649\end{array}$ & \\
\hline Liver $\mathrm{Hg}$ & & & & & $\begin{array}{c}0.26095 \\
0.2532\end{array}$ \\
\hline
\end{tabular}

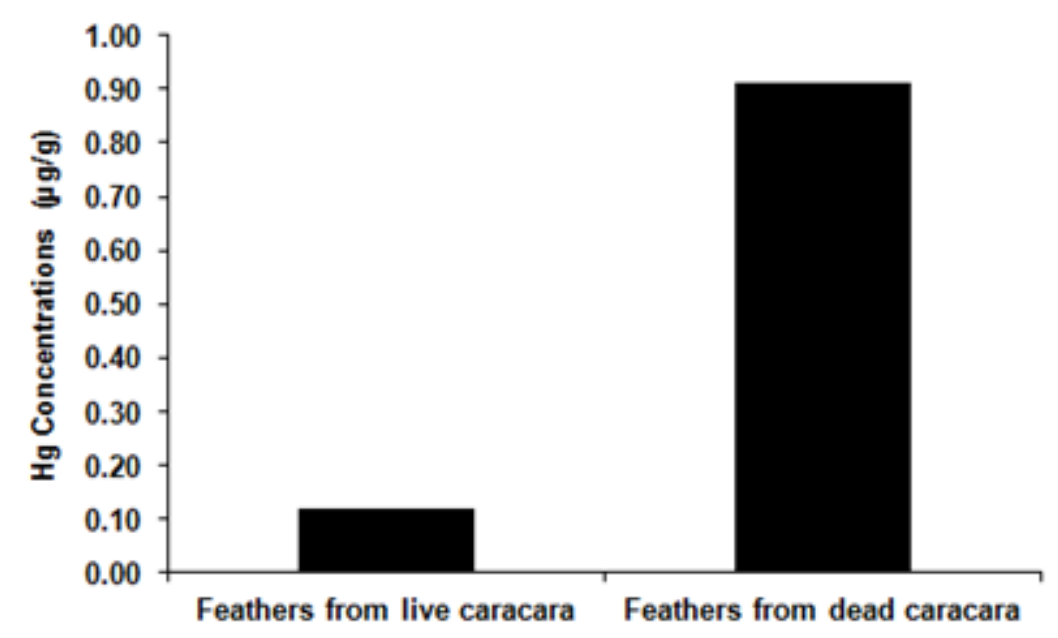

Figure 1. Concentrations of $\mathrm{Hg}(\mu \mathrm{g} / \mathrm{g})$ in live and dead caracaras feathers, Pernambuco, Brazil.

\section{DISCUSSION}

Concentrations of $\mathrm{Cr}$ and $\mathrm{Cu}$ elements were detected in all feather and liver samples analyzed from live and dead caracaras. Chromium, as well as $\mathrm{Hg}$, $\mathrm{Cu}, \mathrm{As}$, and Se have a high affinity for keratin [19], which may explain the higher concentrations of $\mathrm{Cr}$ in caracaras feathers in this research. High concentrations of $\mathrm{Cr}$ in tissues are only observed when body's homeostasis malfunctions and $\mathrm{Cr}$ is assimilated beyond what is necessary for nutrition, causing intoxication [27]. However, this effect was not observed in this study because the levels of $\mathrm{Cr}$ in the liver were lower than those in the feathers studied from dead caracaras.

Pigmentation also influences the endogenous deposition of metals, such as copper, zinc, manganese, and iron due to eumelanin, which is common in black and dark brown feathers like those of caracaras, and has significant binding capacity with these metallic ions [9,22]. High concentrations of $\mathrm{Cu}$ were observed in feathers, which may be attributed to the participation of this element in the keratinization process. However, concentrations were even higher in the liver, which is corroborated by the results obtained in study carried out in Sweden [10], who demonstrated that $\mathrm{Cu}$ is heavily accumulated in the liver and kidneys.

Lead was detected in all liver samples analyzed. Elevated levels were also found in the feathers of dead $(95.2 \%)$ and live $(75.6 \%)$ caracaras. The presence of $\mathrm{Pb}$ may be due to external contamination by pollutants, such as fossil fuels $[8,9,15]$. The deposition of compounds in external parts of the feathers can occur through chemical products, the air, or the uropygial gland of birds [15]. According to research, 50\% to $98 \%$ of the concentrations of $\mathrm{Pb}$ detected in organisms 
can originate from external contamination, although it may also occur due to contaminated feed [10]. It should be considered that the origin of the birds in this study contributes significantly to the results obtained for some metals since the airport region, as well as the surrounding area, is rich in fossil fuels.

Higher concentrations of $\mathrm{Hg}$ were observed in dead caracaras feathers $(\mathrm{P}=0.0459)$ as compared to live ones. Dauwe et al. [9] demonstrated that $\mathrm{Hg}$ concentrations change during molting but are not affected by external contamination. Metals, such as $\mathrm{Hg}$ and $\mathrm{Cd}$, accumulate in organisms from different trophic levels, which may indicate that this contamination comes mainly from feed [19].

In study carried out in Pakistan with laggar falcon (Falco jugger) [20] were found concentrations up to $0.10 \mu \mathrm{g} / \mathrm{g}$ for $\mathrm{Cd}, 1.56 \mu \mathrm{g} / \mathrm{g}$ for $\mathrm{Pb}, 3.09 \mu \mathrm{g} / \mathrm{g}$ for $\mathrm{Hg}$, and $1.98 \mu \mathrm{g} / \mathrm{g}$ for $\mathrm{Cr}$ in the feathers. The concentrations found by us, when compared to this study, were higher only for $\mathrm{Hg}$, which suggests lower environmental contamination or less access to contaminated prey in the region under consideration here. In a similar study in Italy [27] using livers of 52 little owls (Athene noctua), concentrations of $0.17 \mu \mathrm{g} / \mathrm{g}$ for $\mathrm{Cd}, 0.297 \mu \mathrm{g} / \mathrm{g}$ for $\mathrm{Cr}$ and $0.312 \mu \mathrm{g} / \mathrm{g}$ for $\mathrm{Pb}$ were observed. Higher concentrations of metals in both feathers and livers from live and dead birds in our study suggests that Italian birds were less exposed to environmental contamination than the caracaras studied here.

$\mathrm{Pb}$ was investigated in seven birds of the order Falconiformes in Korea [21]. They observed concentrations from 2.9 to $8.1 \mu \mathrm{g} / \mathrm{g}$, on average, for $\mathrm{Pb}$ in the liver of these birds. The concentrations found in our work are lower for both liver and feathers, possibly due to the greater urbanization in Korea, which increases the number of pollutants in the atmosphere and consequently exposes more birds. In studied four birds from the order Falconiformes in Pakistan [1] the authors to report concentrations of $2.70 \mu \mathrm{g} / \mathrm{g}$ for $\mathrm{Pb}, 1.00 \mu \mathrm{g} / \mathrm{g}$ for $\mathrm{Cd}, 1.55 \mu \mathrm{g} / \mathrm{g}$ for $\mathrm{Cr}$, and $5.06 \mu \mathrm{g} / \mathrm{g}$ for $\mathrm{Cu}$. When compared, the concentrations of metals in caracaras were higher for $\mathrm{Pb}, \mathrm{Cr}$, and $\mathrm{Cu}$ indicating that they were more exposed to environmental contamination either through atmospheric and feather deposition or through contaminated prey.

Pearson's coefficient here showed no correlation between metals from dead caracaras feathers and livers, although a few previous studies have shown a correlation between metal concentrations from tissues and feathers [2,16,17]. No positive correlation also was found between the metals studied in feathers and livers of three different species of predators in study realized in Galicia, Spain [6]. This pattern can be attributed to the different time of exposure of feathers to metals in relation to livers. The concentrations of metals in hepatic tissues reflect the levels of elements in the diet of these birds, characterizing acutely the contamination of the ecosystem. On the other hand, feathers represent the exposure in the time of molting, when the artery supplies metals, thus representing a chronic exposure.

In feathers from live birds, the Pearson's correlation analysis showed a high to moderate correlation between metals, which may suggest that they come from a similar source, but there is no way to specify the origin since the metals surveyed could be present in the soil, water, or in the prey eaten by these animals. For the purpose of environmental analyses, it is required to determine the exact source of contamination.

A high positive correlation was found between dead caracaras feathers for $\mathrm{Pb}$ and $\mathrm{Cd}(\mathrm{r}=0.74, P<$ $0.0001)$ and $\mathrm{Cr}$ and $\mathrm{Cu}(\mathrm{r}=0.80, P<0.0001)$. This means that higher the concentration of $\mathrm{Pb}$ and $\mathrm{Cr}$ in feathers, higher was the concentration of $\mathrm{Cd}$ and $\mathrm{Cu}$, respectively. These data suggests that metals come from the same source, possibly from the environment, because these concentrations can be influenced mainly by the levels of these metals in water, sediments, and air. The levels of $\mathrm{Pb}$ and $\mathrm{Cd}$ are directly correlated with prey and slightly with external contamination. A high $\mathrm{Pb}$ level is indicative of environmental pollution [14]. Concentration of $\mathrm{Cu}$, on the other hand, can vary with diet and environmental contamination of water, sediments, and effects of industrialization [17]. Similarly, $\mathrm{Cr}$ is present in parts of industrial processes, which lead to contaminating the environment [26]. In their study, a high correlation between $\mathrm{Cu}$ and $\mathrm{Cr}(\mathrm{r}=0.80$; $P<0.0001$ ) was found, which may be due to the high affinity of keratin for these elements [19].

In this study, a high positive correlation was found between $\mathrm{Cu}$ and $\mathrm{Hg}(\mathrm{r}=0.79, P<0.0001)$ and a moderate correlation was found between $\mathrm{Cd}$ and $\mathrm{Cu}(\mathrm{r}=0.43, P=0.0532)$ as well as $\mathrm{Cu}$ and $\mathrm{Hg}(\mathrm{r}=$ $0.51, P=0.0172$ ), which can be explained by the fact that the liver is a deposition organ for metals. In the case of $\mathrm{Hg}$, accumulation and excretion in the liver is very important, although the deposition of this metal 
is greater in feathers [5]. Copper is stored in hepatocytes for the synthesis of copper-dependent enzymes, so higher concentrations in this organ are expected $[11,12]$. Although Cd concentrations are generally higher in the kidneys, liver also significantly accumulates this metal. In cases of chronic exposure to $\mathrm{Cd}$, liver represents a good biomarker for total exposure to this metal [23]. The concentration of metals can vary considerably, when the feeding habits of birds are being considered. Metals like $\mathrm{Cr}$ and $\mathrm{Cu}$ exhibit affinity for birds of carnivorous habit, while $\mathrm{Pb}$ exhibits affinity for saprophagous birds as well as the caracaras, which are generalist species [1].

As far the toxicity of these metals is concerned, is reported that only concentrations of $\mathrm{Cd}$ up to 3 and $10 \mu \mathrm{g} / \mathrm{g}$ are toxic in birds [27]. Concentrations of $\mathrm{Pb}$ below $6 \mu \mathrm{g} / \mathrm{g}$ function only as background concentrations and are lethal only when above $25 \mu \mathrm{g} / \mathrm{g}$ [21]. Concentrations of $\mathrm{Hg}$ were low in the subjects studied in this research, probably due to the source of $\mathrm{Hg}$ being the primary food, i.e., poisoning occurs primarily in piscivorous birds, which is not the case with caracaras [13]. Both $\mathrm{Cu}$ and $\mathrm{Cr}$ are metals required by the body. It is known that $5-10 \mathrm{mg} / \mathrm{kg}$ of $\mathrm{Cu}$ are required in the diet of poultry with the maximum concentration that can be tolerated being $250 \mathrm{mg} / \mathrm{kg}$; however, physiology is not the same in different species of birds, and thus, specific studies need to be performed to determine the threshold for intoxication [3]. In case of $\mathrm{Cr}$, it is difficult to evaluate the concentration required to determine intoxication, because the homeostasis mechanism acts as a defense, preventing high concentrations from being absorbed [27].
The development of systematic research on animals and the environment is essential for the monitoring of levels of heavy metals and evaluation of the impact caused by them in order to guide measures to protect flora, fauna, and human health.

\section{CONCLUSION}

It was possible to confirm the presence of heavy metals in feathers and livers from free-living southern caracaras in Northeastern region of Brazil, signaling that these birds can be important environmental bioindicators. The detection of heavy metals in birds provides a diagnosis of the environmental situation and raises concerns regarding the exposure of other species as well as humans to these potentially toxic compounds.

\author{
MANUFACTURERS \\ ${ }^{1}$ Labcon North America. Petaluma, CA, USA. \\ ${ }^{2}$ CEM Corporation. Matthews, NC, USA. \\ ${ }^{3}$ PerkinElmer Inc. Winter St Waltham, MA, USA. \\ ${ }^{4}$ Varian Australia Pty Ltd. Mulgrave, VIC, Australia. \\ ${ }^{5}$ Agilent Technologies Inc. Mulgrave, VIC, Australia. \\ ${ }^{6}$ SAS Institute Inc. Cary, NC, USA.
}

Acknowledgements. We thank the Coordination and Improvement of Higher Education Personnel (CAPES - Brazil).

Ethical approval. Brazilian Institute of Environment and Renewable Natural Resources (IBAMA) No. 005 F / 2011 and the Ethics Committee on the Use of Animals (License No. 078/2016) from Federal Rural University of Pernambuco.

Declaration of interest. The authors declare that they have no conflict of interest that is directly or indirectly related to this research.

\section{REFERENCES}

1 Abbasi N.A., Jaspers V.L.B., Chaudrhry M.J.I., Ali S. \& Malik R.N. 2015. Influence of taxa, trophic level, and location on bioaccumulation of toxic metals in bird's feathers: A preliminary biomonitoring study using multiple bird species from Pakistan. Chemosphere. 120: 527-537.

2 Agusa T., Matsumoto T., Ikemoto T., Anan Y., Kubota R., Yasunaga G., Kunito T., Tanabe S., Ogi H. \& Shibata Y. 2005. Body distribution of trace elements in Black-tailed Gulls from Rishiri Island, Japan: age dependent accumulation and transfer to feathers and eggs. Environmental Toxicology Chemistry. 24(9): 2107-2120.

3 Apsïte M., Bërzina N. \& Basova N. 2012. Effects of high but non-toxic dietary intake of Selenium and Copper on indices of the antioxidant defense system and on accumulation of trace elements in Chicks. Proceedings of the Latvian Academy of Sciences B. 66(3): 117-124.

4 Burger J. \& Gochfeld M. 1997. Risk, mercury levels, and birds: relating adverse laboratory effects to field biomonitoring. Environmental Research. 75(2): 160-172.

5 Burger J. \& Gochfeld M. 2000. Metals in albatross feathers from midway atoll: influence of species, age, and nest location. Environmental Research. 82(3): 207-221. 
6 Castro I., Aboal J.R., Fernandéz J.A. \& Carballeira A. 2011. Use of Raptors for Biomonitoring of Heavy Metals: Gender, Age and Tissue Selection. Bulletin of Environmental Contamination and Toxicology. 86(3): 347-351.

7 Cui J., Wu B., Halbrook R.S. \& Zang S. 2013. Age-dependent accumulation of heavy metals in liver, kidney and lung tissues of homing pigeons in Beijing, China. Ecotoxicology. 22(10): 1490-1497.

8 Dauwe T., Bervoets L., Blust R. \& Eens M. 2002. Tissue levels of lead in experimentally exposed zebra finches (Taeniopygia guttata) with particular attention on the use of feathers as biomonitors. Archives of Environmental Contamination and Toxicology. 42(1): 88-92.

9 Dauwe T., Bervoets L., Pinxten R., Blust R. \& Eens M. 2003. Variation of heavy metals within and among feathers of birds of prey: Effects of molt and external contamination. Environmental Pollution. 124(3): 429-436.

10 Ek K.H., Morrison G.M., Lindberg P. \& Rauch S. 2004. Comparative tissue distribution of metals in birds in Sweden using ICP-MS and laser ablation ICP-MS. Archives of Environmental Contamination and Toxicology. 47(2): 259-269.

11 Fuentealba C. \& Aburto E.M. 2003. Animal models of copper-associated liver disease. Comparative Hepatology. 2: 5. [Fonte: https://www.ncbi.nlm.nih.gov/pmc/articles/PMC156612/pdf/1476-5926-2-5.pdf>]. [Accessed online in March 2015].

12 Gaetke L.M., Chow-Johnson H.S. \& Chow C.K. 2014. Copper: toxicological relevance and mechanisms. Archives of Toxicology. 88(11): 1929-1938.

13 Gomes A.L., Vieira J.L.F., Pinheiro M.C.N. \& Marceliano M.L.V. 2009. A first evaluation on the use of Ardea albus feathers as bioindicators of mercury burden in Amazonian ecosystems. Acta Amazonica. 39(4): 969-971.

14 Janaydeh M., Ismail A., Zulkifli S.Z., Bejo M.H., Aziz N.A. \& Taneenah A. 2016. The use of feather as an indicator for heavy metal contamination in house crow (Corvus splendens) in the Klang area, Selangor, Malaysia. Environmental Science and Pollution Research. 23(21): 22059-22071.

15 Jaspers V.L.B., Covaci A., Van den Steen E. \& Eens M. 2007. Is external contamination with organic pollutants important for concentrations measured in bird feathers? Environment International. 33(6): 766-772.

16 Kim J. \& Oh J.M. 2012. Monitoring of heavy metal contaminants using feathers of shorebirds, Korea. Journal of Environmental Monitoring. 14(2): 651-656.

17 Kim J. \& Oh J.M. 2014. Relationships of Metals Between Feathers and Diets of Black-Tailed Gull (Larus crassiorostris) Chicks. Bulletin of Environmental Contamination and Toxicology. 92(3): 265-269.

18 Little T.M. \& Hills F.J. 1978. Agricultural experimentation: design and analysis. New York: John Wiley and Sons, 368p.

19 Lodenius M. \& Solonen T. 2013. The use of feathers of birds of prey as indicators of metal pollution. Ecotoxicology. 22(9): 1319-1334.

20 Movalli P.A. 2000. Heavy metal and other residues in feathers of laggar falcon (Falco biarmicus jugger) from six districts of Pakistan. Environmental Pollution. 109(2): 267-275.

21 Nam D. \& Lee D. 2011. Mortality factors and lead contamination of wild birds from Korea. Environmental Monitoring and Assessment. 178(1-4): 161-169.

22 Niecke M., Heid M. \& Krüger A. 1999. Correlations between melanin pigmentation and element concentration in feathers of white-tailed eagles (Haliaeetus albicilla). Journal of Ornithology. 140(3): 355-362.

23 Scheuhammer A.M. 1987. The chronic toxicity of aluminium, cadmium, mercury, and lead in birds: A review. Environmental Pollution. 46(4): 263-295.

24 Sick H. 1997. Ordem Falconiformes. In: Sick H. (Ed). Ornitologia Brasileira. 3.ed. Rio de Janeiro: Nova Fronteira, pp.243-269.

25 Travaini A., Donázar J.Á., Ceballos O. \& Hiraldo F. 2001. Food habits of the Crested Caracara (Caracara plancus) in the Andean Patagonia: the role of breeding constraints. Journal of Arid Environments. 48(2): 211-219.

26 Tsipoura N., Burger J., Ross Feltes R., Yacabucci J., Mizrahi D., Jeitner C. \& Gochfeld M. 2008. Metal concentrations in three species of passerine birds breeding in the Hackensack Meadowlands of New Jersey. Environmental Research. 107(2): 218-228.

27 Zaccaroni A., Amorena M., Naso B., Castellani G., Lucisano A. \& Stracciari G.L. 2003. Cadmium, chromium and lead contamination of Athene noctua, the little owl, of Bologna and Parma, Italy. Chemosphere. 52(7): 1251-1258. 